\title{
Nature and Types of Schools In pre independence India
}

\author{
Ratnesh Ranjan ${ }^{1}$, Anuradha Pandey ${ }^{2}$, V. Ranjan ${ }^{3}$ \\ ${ }^{I}$ Directorate of Education, Government of NCT of Delhi, Delhi, India \\ ${ }^{2}$ Tathagat Teachers' Training College, Dhanbad, India \\ ${ }^{3}$ ISM Dhanbad, India
}

\begin{abstract}
In this paper, nature and types of schools prevailing in India during pre-independence period during $18^{\text {th }}$ century till the year 1947 has been discussed. The various educational policies, practices and their impact on the society have been elaborated. The contributions of the public schools to the society in different cultural, scientific and industrial development has been assessed.
\end{abstract}

Keywords: school, public, private

\section{INTRODUCTION}

The nomenclature "Public School" [1] has two different meanings in Britain and America. In Britain, Public Schools are those schools which are run by private people and the expenses incurred on education are totally met by students and their guardians. Whereas, in America, Public Schools are those, which are opened in your locality and the expenses on education are totally carried out by Government itself. Students do not have to pay for their Education. In India we follow the British nomenclature of Public School.During British period, three types [2] of Institutes were opened. First were the governments schools, which were run by government itself and the expenditure on management, were met by government. Students had to pay nominal fee. The second type of schools was opened by social workers. It was thought that British government education was not conducive to Indians. It was felt that Indian cultural tradition must not be overlooked. So Indian cultural aspects had to be included in the syllabus. Such types of institutes /schools aimed at two facets-one, they wanted to teach students the British way of education and another, they wanted to maintain Indian cultural traditions as well. And undoubtly English played a dominant role in subsequent days. We see that in DAV schools, which fall under this type of schools English has become a dominant language whereas Vedic culture has diminished day by day.The third type of schools was opened by different missionaries. These schools were opened to publicize Christianity. Such Schools were given names as "St", "Convent". No doubt the middle class people who were unable to send their children away to Doon School and who felt that government and Anglo-Vedic schools are no longer 'Anglo' started sending their children to these missionary schools named after "St" and convent".Indeed Government schools have witnessed indifference towards works to a great extent. But this is not the only reason for the growth of public schools. In fact our society began to divide on new pattern, after independence. The upper class started keepingthemselves in isolation. Such people left their old patterned houses to shift in civil lines areas. They chose schools of hill stations for their children. Schools running in their neighboring areas were looked down upon by these high up societies. These led to the emergence of new township, apartments and also public schools.

Public Schools were of the opinion that even though the national policy is to impart education in Hindi media, English will play a dominant role in getting higher services. Thus the government schools which became the laboratory of different government policies continued to lag behind in comparison to Public Schools. In North Indian Hindi speaking states like Bihar and Uttar Pradesh, English as a subject was made non compulsory. This is not all, different political parties propagated that official work was to be done in Hindi language only. But in practice result was totally different. English became more and more important. At international level also the importance of English increased sharply.

Thus two way of educational system began to develop. One, which gave importance to English language right from beginning. And the other, which supposed that English is not necessarily needed. But soon the middle class people felt that in economic and administrative area, they are not being accepted on the ground that "they are unable to work in English. As the secret began to reveal, the middle class people desperately felt the need for English. This was not limited to the knowledge of English language only, but these people wanted to be accepted by the so called elite class English speaking people. Government school could not provide such type of atmosphere to these people. It was the "Atmosphere" for which public schools grown like an industry. 


\section{Indigenous Schools:}

Towards the end of the $18^{\text {th }}$ century there was a fairly wide network of indigenous educational instituition [4]: They were broadly of two types, the schools of higher learning, which included Hindu Pathsalas and Muslim Madarsahs and the indigenous elementary schools both Hindu and Muslim. The Hindu schools were mostly attended by boys and generally excluded the untouchable castes and girls, except in a few areas. The Muslim schools Maktabs-were usually attached to the mosques. Along with the boys a few girls also attended them at a young age. But in richer families the practice was to educate them at home. The chief merits of the system were its universality (almost every village had a school and a bigger villages and towns had several), its adaptability to local environment, and the vitality and popularity it had acquired by centuries of existence under a variety of economic conditions and political vicissitude.

\section{Efforts Of East India Company 1780-1813}

Warren Hastings established a Madarsah at Calcutta in 1781 "to conciliate the Mohammedans of Calcutta" and "to quality the sons of Mohammedan gentlemen for responsible and lucrative office in the state." Similarly Jonathan Duncan, the resident of Varanasi, founded a Sanskrit collage there in 1792 with an object of "endearing our government to the native Hindu" and of providing "a nursery of future doctor and expounders (of Hindu law) to assist European Judges." The Company declined to do anything beyond the maintenances of these two institutions. Meanwhile educational enterprise of an entirely different kind was being evolved by the missionaries. They started elementary schools from the humblest strata of society, including the untouchable castes. They also established schools for teaching English, which was slowly beginning to come into prominence.

\section{Educational Experiments:}

The charter act of 1813 required the company to set apart "a sum of not less than one lakh of rupees each year" for the revival and improvement of literature and the encouragement of learned natives of India and for the introduction and promotion of knowledge of science among the inhabitants of the British territories in India.Lord William Bentinck adopted English as the official language of the government and Lord Harding decided, in 1844, to give employment under the government to Indians educated in English schools. The success of English education was thus assured and it made tremendous progress in Bengal between 1813 and 1854.

Mount Stuart Elphinstone, Governor of Bombay (1819-27) was in favour of instruction based on a study of three languages. The native education society of Bombay, established in 1822 mainly at his instance, started a large number of schools for teaching English as well as Indian languages, trained up teachers and published a large number of books in Indian languages. But ultimately, English was adopted as the sole medium of instruction at the collegiate stage. Till the end of the secondary stage, however both English and Modern Indian languages were continued as media of instruction.

James Thomason, the lieutenant-Governor of the north-western provinces, was the first to levy a cess on land revenue for the spread of mass education. With the proceeds of this cell and an equal grant -in -aid from government funds, he established a large number of primary schools in selected villages. He also organized a good system of inspection, which included a visitor in each pargana a zila visitor in each district, and a visitor general for the province as a whole.

Three other developments of this period deserve notice. The first was the great upsurge in missionary activities. Pioneer work in almost every field of education was done by the missionaries of the time. The second, important development was the establishment of medical, engineering and law colleges, which marked a beginning in professional education. But the most significant event was the official sanction accorded to the education of girls, for which Lord. Dalhousie offered the open support of government.

\section{Wood's Dispatch Of 1854}

Sir Charles Wood's Dispatch declared emphatically that the main objective of educational policy should be the diffusion of "the improved arts, science, philosophy and literature of Europe "through the medium of English as well as the modern Indian languages. It suggested that below the universities there should be a network of institutions which would include colleges, high schools teaching through English or Modern Indian language and primary schools, most of which would be the indigenous elementary schools assisted by suitable grants in aid. The dispatch also emphasized the development of private enterprise, missionary as well as Indian, through a proper system of grant-in-aid and suggested the training of teachers in normal schools, the conferment of govt. jobs in educated person, and increased attention to the development of education among young girls and woman.

In the next 50 years the policies laid down by the Dispatch of 1854 were slowly and steadily implemented. The Indian Education Commission of 1882 recommended that the government should maintain only a few colleges, secondary schools and other essential institutions and that the rest of the field should be left 
to private enterprise. This recommendation was accepted. The missionaries adopted a policy of voluntary restriction of the expansion of their educational activities, deciding to maintain only a few good institutions, they were meant primarily for the Christians but were opened to all thus it was a private enterprise that provided the bulk of the growing number of collages and secondary schools which the country needed.

\section{Secondary Education}

Secondary education expanded fast during this period and by 1901-02 the total number of secondary schools in the country grew to 5,124 with 5,90,129 pupils. Almost all of them were 'unilateral' academic institution which prepared students for the university entrance examination. Another characteristic of the secondary school of this period was that they were conducted mostly by Indian private enterprise. As government grants to the schools were meager, secondary education mainly depended for financial support on fees and donations and could be kept going because the teachers agreed to work of low salaries.

\section{Primary Education}

Most of the indigenous schools died out during this period, either through competition with government schools or through neglect. The most important event of this time in the field of primary education was the levy of a local cess or rate of education, recommended in the educational dispatch of 1854 . By 1882, the levy was imposed in all areas except (such as Bengal) where the permanent settlement of land revenue created a legal obstacle. When municipalities began to be established in towns and cities, they also contributed money for primary education. Further grants -in -aid from state funds began to be sanctioned to supplement local funds. All these measures increased the resources available to primary education and laid to its expansion. The Indian Education Commission recommended the transfer of primary education to local bodies. The measure led to an immediate gain by way of availability of additional funds. However, since the resources of the local bodies were inelastic and restricted, the transfer of control acted ultimately to the disadvantage of primary education and held up further progress.

As compared to the indigenous schools, which dominated the scene prior to 1854 , the new type of primary schools, registered a certain degree of qualitative improvement. By 1901, the primary teachers were better qualified and a fair percentage of them were trained. The schools were now provided wherever possible, with buildings of their own. They were also better equipped and used printed books. Their curriculum was broader and though mainly academic, it now included kindergarten or "object lessons". History, Geography, Hygiene, Agriculture Science and Physical Exercises. Better methods of teaching were generally adopted and, on the whole the standard of teaching showed improvement. The readiness of these schools to admit girls and scheduled caste students gave them another distinct advantage over the indigenous ones. But as these schools merely replaced the old indigenous institutions, the rate of overall progress in mass education was almost negligible. In fact, there is reason to believe that the percentage of literacy for man in 1901 was even lower than that in 1835 .

\section{Period Of Transition 1901 To 1921}

Lord Curzon convened the first conference of Directors of public instruction in 1901 and initiated an era of educational reform based on its decisions. Government secondary schools were, largely improved though such measures as the strengthening of staff and the provision of hostels-they were meant to serve as models for private enterprise. The Government tightened its control by increasing the inspection staff and by insisting that every secondary school must seek recognition from the department aid or no aid, the conditions of recognition were fairly strict. The expansion of secondary education was even more rapid than in the earlier period of laissez -faire, from 5493 schools with 6, 23,000 students in 1901-02 to7530 schools with 11,06,803 students in 192122. Attempts were made in this period to diversify secondary education, provide vocational courses, and reduce the domination of English by adopting the modern languages of India as media of instruction. But the success achieved was very limited and the major defects of secondary education noticed in the earlier period continued to persist.

The government strove to expand primary education by giving larger grant -in-aid to local bodies, but it also laid great emphasis of improvement of quality. For this purpose, the salaries of teachers were raised, the curricula were widened and the training of teacher and also the adoption of better methods of teaching were stressed. The Bombay legislature was the first to pass a law introducing compulsory primary education in urban areas in 1918. This example was followed by several other provinces, which enacted similar laws owing partly to the larger financial support made available by the government and party to popular enthusiasm, the expansion in the field of primary education was very great, the number of primary schools rising from 93604 in 1901-02 with 3076671 children to 155017 in 1921-22 with 6.1 million children.

It was this period that the concept of national education was first put forward by a number of great leaders such as Mrs. Annie Besant, LalaLajpatRai, Mahatma Gandhi. They held that the system of education, as 
it then existed was unhelpful and even antagonistic to national development. A national system of education for India they said should be subject to Indian control and it should foster love of the motherland. Freed from the domination of English, it should emphasize technical and vocational education and try to build up the national character.

\section{Education Under Indian Control (1921-47)}

From 1921 to 1947, education was under Indian control in the sense that it was under the new act, a provincial subject administered by a minister responsible to the provincial legislature. There was an unprecedented expansion in secondary and primary education. The number of high schools rose to 5297 and that of middle schools to 12,843 . The total enrolment at the secondary stage rose to $29,06,921$ which were about 2.5 times that in 1921.From the qualitative point of view, a definite gain was the adoption of the modern Indian languages as media of instructions, though English continued to be studied as a compulsory subject. Another gain was the improvement in the training of teachers and the starting of a large number of technical commercial and agricultural high schools .On the other hand there was a predominance of academic schools the low salaries and the generally unsatisfactory conditions of service for teacher, non selective admissions leading to the inrush of unfit student and the absence of an adequate system of scholarships for the support of promising students.

In the field of primary education, the progress was considerable. Most provinces passed compulsory education laws and introduced it in a few selected urban and rural areas, the power of local bodies over primary education was increased, the salaries of teachers were raised and the arrangements for their training improved. The number of schools increased to 1, 72,661 of nearly 2.5 times that in 1921-22. In spite of this expansion, only about 35 per cent of the children were enrolled in the age group 6-11 and in the age group 11-14, the enrolment was as low as 9 percent. Moreover, because of shortage of funds the system continued to be predominantly academic in spite of attempts to introduce extra curricular activities. With a view to changing this academic character of the system and making it less costly Mahatma Gandhi propounded in 1937 his scheme of basic education. It was accepted by the congress ministries in principles, but they were in office only for a very short time and the scheme did not go beyond the experimental stage.

Two of the promising achievements of this period were to be found in the field of women's education and the education of the backward classes. In 1947 the total number of girls under instruction was 42,97,785 of whom about 6.02,280 in secondary schools, 34,75,165 in primary schools, 56,090 in special schools and $1,41,043$ in unrecognized institutions. Equally creditable were the results of the spread of education among the backward classes. Following the lead given by Mahatma Gandhi, the popular ministries allowed very liberal educational concessions to the backward classes in general and the scheduled classes and tribes in particular. Consequently education spread rapidly among these classes although they had still a long way to go. This period was also conspicuous for the small beginning made in the programmers of adult education. The movement, however, could not be organized on a mass scale and its progress varied from provinces to provinces.

Thus by 1947, the modern system of education created by the British was nearly 150 years old. Its main contribution was to bring Indians into contact with scientific and industrial development as well as the thought and the social and political philosophy of the west. This contact had in many ways a verifying effect. It freed the Indian mind from the "thralldom of old -world ideas." And initiated a renaissance in Indian life which led to a scientific and critical study of our cultural heritage and to the rediscovery of our ancient arts of painting, architecture and sculpture, it also resulted in the enrichment of modern Indian languages and the development and revival of humanistic trends. Finally the awakening of political consciousness and his struggle for freedom which culminated in the attainment of independence in 1947 can also be largely traced to the social forces released by modern education.

\section{SCHOOLS DURING The BRITISH DAYS}

The colonial regime prior to our Independence in 1947, established a system of education that had limited access and denied mass education. It gave greater emphasis on conformism to socio- political and economic systems obtained in the country in those times. Macaulay explicitly stated that the objective of the education system was to create a new breed of Indians as similar to Europeans as possible [3]. It was on this account that the Indian national movement developed a strong critique of the British system that only imparted 'learning skill'. It did not respect Indian tradition, which expressed the global sentiments of education for all.

\section{Conclusions:}

During pre-independence period of India, different types of public and private educational schools existed. The contributions of the public schools to the society in different cultural, scientific and industrial development particular in women education and the education to the backwards and in the increase in the number of enrolments were more prominent during 1021-47. 


\section{References:}

[1] Shukla Vagish, "SIRF SHAUK NAHI MAJBURI BHI“, Hastakshep (Rastriya Sahara),New Delhi Dated 20 December 1997 Page No.4

[2] IBID

[3] MohantyBiswarajan "Nation Building and Elementary Education", EN VOL XXV NO-50 Dated 10-16 March 2001, New Delhi. Page No-01

[4] Chopra .P.N. "Society, Religion and Literature", The Gazetteer of India, Indian Union Vol-2, Publication Division, Govt. of India, Patiala House New Delhi, DEC.-1990 Page No-655(4-A) Source: Deptt. Of Higher Education, Ministry of HRD, Government of India.

[5] Prasad Bandhu, The Bihar Education Code 2001, Malhotra Brother, Patna, Page -7.

[6] IBID, Page-1.

[7] Khan, Alim Jung, Dy. Director of Education, Bihar "Compendium of Circulars of Minority \& Public High School”, 2000, Malhotra Brothers, Freser Road, Patna, Part IT, Page No.01.

[8] Singh, Abhimanyu, "Progress of Education in India Since 1950"- Abhimanyu Singh, An Overview,-" EN 2-8 SEP. 2000, New Delhi, Page-2

[9] Hastakshep (Rastriya Sahara), Page -2, Dated 20 Dec. 1997.

[10] Khan, Alim Jung, DDE, Bihar "Compendium of Circulars of Minority and Public High Schools" 2000, Malhotra Brothers, Patna, Part IT, Page No-03, 02 